\title{
Techno-Economic Analysis on the Production of Copper Oxide Nanoparticles by Green Synthesis Method using Abultion indicum Leaf Extract on an Industrial Scale
}

\author{
R. F Putra1, C Satari , R. S Sidqi, S. R Putri, A. B. D Nandiyanto* \\ 1Departemen Pendidikan Kimia, Universitas Pendidikan Indonesia, Indonesia \\ Email: *nandiyanto@upi.edu
}

\begin{abstract}
The purpose of this study was to evaluate the economic feasibility of producing copper oxide $(\mathrm{CuO})$ nanoparticles using the green synthesis method on an industrial scale for 10 years by evaluating from an engineering and economic perspective. Various economic parameters are used to analyze economic viability, including Gross Profit Margin (GPM), Cumulative Net Present Value (CNPV), Payback Period (PBP), as well as economic variations in sales, taxes, raw materials, labor wages, and utilities to ensure project feasibility. Technical analysis to produce $100 \mathrm{~kg}$ of $\mathrm{CuO}$ nanoparticles per day requires a total production cost of 220,322.850.00 IDR and the gross profit margin is $16,721,250.000,00$ IDR per year. PBP analysis shows that the investment will be profitable after more than three years. This project can compete with PBP capital market standards because of the short investment return. The profit is relatively economical, so this project can be run for 10 years under ideal conditions. This research is expected to be a reference for technical and economic analysis of industrialscale production of $\mathrm{CuO}$ nanoparticles.
\end{abstract}

\section{Introduction}

$\mathrm{CuO}$ is a particularly interesting and promising transition metal oxide [1] because of its very wide application such as batteries [2], heterogeneous catalysts [3], solar cells [4], optics [5], hydrogen storage material [6], and medical applications [7]. In addition, $\mathrm{CuO}$ nanoparticles have demonstrated their potential in pharmacological activity, particularly in antitumor therapy [8].

There are several methods of $\mathrm{CuO}$ synthesis that have been reported by several researchers, including direct electrochemical method $[9,10,11]$, sonochemisrty $[12,13,14]$, sol-gel $[15,16$, 17], hydrothermal [18, 19, 20], biogenic [21, 22, 23], and green synthesis [24, 25, 26]. In general, nanoparticle synthesis methods are very expensive, and can be hazardous to the environment and organisms [27]. Therefore, looking for other friendly techniques such as green synthesis has received great attention from researchers to develop green chemistry and bioprocesses [28]. The green synthesis method is considered to have the highest efficiency, because the method is simple and more economical than other methods, produces minimal waste and is easy to handle [29]. 
Chemical industry economic evaluation is a form of quantitative assessment of what people expect and want to invest in a project [30]. This evaluation analysis uses several parameters such as Gross Profit Margin (GPM), Cumulative Net Present Value (CNPV), Payback Period $(\mathrm{PBP})$, and economic variations in sales, taxes, raw materials, labor wages, and utilities to ensure project viability.

Therefore, the purpose of this study is to determine the feasibility of the project for the manufacture of $\mathrm{CuO}$ nanoparticles using the green synthesis method by conducting technical and economic evaluations. In this study, we vary several factors to see their effect on the economic evaluation under study, such as decreases and increases in product prices, increases in taxes, and variable costs (raw materials, labor, and utilities).

\section{Method}

\section{Theoretical Synthesis of CuO Nanoparticles}

Figure 1 shows the stages of the synthesis of $\mathrm{CuO}$ nanoparticles using the green synthesis method with Abultion indicum leaf extract as fuel. The $\mathrm{CuO}$ nanoparticle synthesis method was adopted from research conducted by [29]. Abultion indicum leaf extract was prepared by washing and drying the leaves at room temperature $\left(22-25^{\circ} \mathrm{C}\right)$ for 15 days. Then, the leaves were grinded with a grinder until smooth to be extracted by the Soxhlet method using water at a temperature of $90-95^{\circ} \mathrm{C}$ for 3 hours. The extract is filtered and concentrated using an evaporator to separate the extract from the residue. The extract is then dried using a water bath and stored in the refrigerator. $\mathrm{CuO}$ nanoparticles were synthesized by mixing $301.25 \mathrm{~kg}$ of $\mathrm{Cu}\left(\mathrm{NO}_{3}\right)_{2} \cdot 3 \mathrm{H}_{2} \mathrm{O}$ with $75 \mathrm{~kg}$ of leaf extract prepared in $5000 \mathrm{~L}$ of double distilled water. The solution was homogenized for 10 minutes using a magnetic stirrer at a speed of $2000 \mathrm{rpm}$. The homogenized sample was then burned in a furnace at $400^{\circ} \mathrm{C}$ for $2-3$ minutes to produce $\mathrm{CuO}$ particles. The mixture is filtered to remove the ash (carbon) content of the plant extract. Furthermore, $\mathrm{CuO}$ nanoparticles were calcined at the same temperature for 2 hours to achieve purity. Pure $\mathrm{CuO}$ nanoparticles stored in airtight containers. 


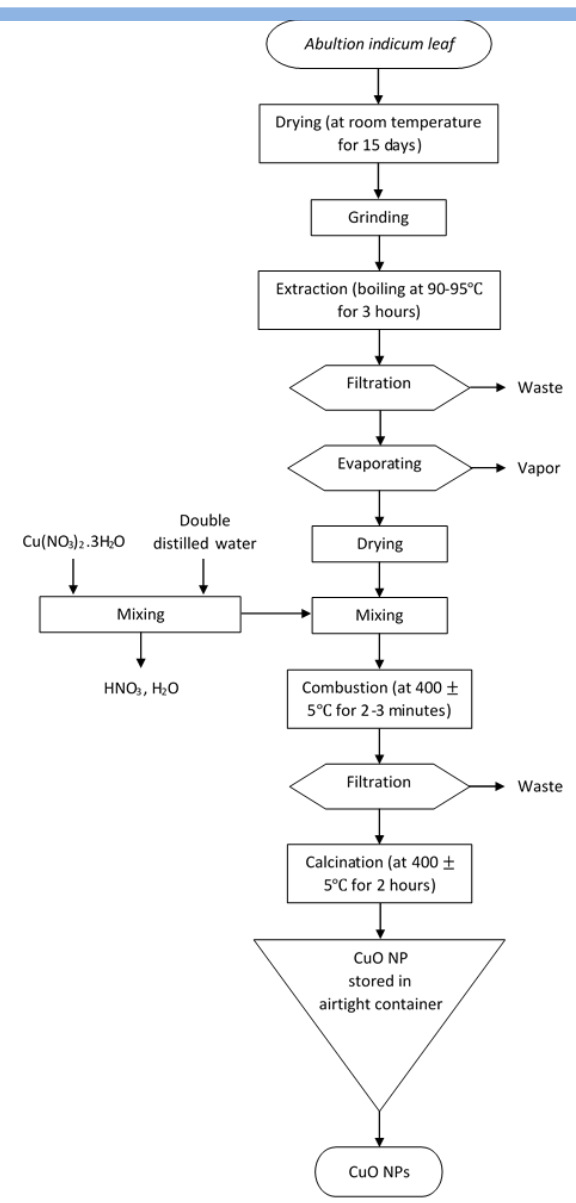

Figure 1. Schematic of synthesis of $\mathrm{CuO}$ nanoparticles

\section{Energy and Mass Balance}

The materials needed for the synthesis of $\mathrm{CuO}$ nanoparticles are 0.3 grams of Abultion indicum leaf extract, 1.205 grams of $\mathrm{Cu}\left(\mathrm{NO}_{3}\right)_{2} \cdot 3 \mathrm{H}_{2} \mathrm{O}$, and $20 \mathrm{~mL}$ of double distilled water. The formation of $\mathrm{CuO}$ follows the following reaction equation:

(1) $\mathrm{Cu}\left(\mathrm{NO}_{3}\right)_{2} \cdot 3 \mathrm{H}_{2} \mathrm{O}_{(\mathrm{s})}+\mathrm{H}_{2} \mathrm{O}_{(\mathrm{l})} \rightarrow \mathrm{Cu}(\mathrm{OH})_{2(\mathrm{~s})}+2 \mathrm{HNO}_{3(\mathrm{aq})}$

(2) $\mathrm{Cu}(\mathrm{OH})_{2(\mathrm{~s})} \rightarrow \mathrm{CuO}_{(\mathrm{s})}+\mathrm{H}_{2} \mathrm{O}_{(\mathrm{l})}$

From a technical point of view, it is possible to increase the production of $\mathrm{CuO}$ nanoparticles because the capacity and quantity of the tools and materials used can be enlarged. To produce $100 \mathrm{~kg}$ of $\mathrm{CuO}$ nanoparticles in one day, it takes a reaction cycle of about $75 \mathrm{~kg}$ of Abultion indicum leaf extract, $301.25 \mathrm{~kg}$ of $\mathrm{Cu}\left(\mathrm{NO}_{3}\right)_{2} \cdot 3 \mathrm{H}_{2} \mathrm{O}$ and $5000 \mathrm{~L}$ of double distilled water.

Several assumptions were made to synthesize $\mathrm{CuO}$ nanoparticles on an industrial scale and were based on stoichiometric and mass balance calculations.

1. The nanoparticle synthesis process is carried out using the green synthesis method.

2. All materials used in the synthesis reaction of $\mathrm{CuO}$ nanoparticles such as double distilled water, $\mathrm{Cu}\left(\mathrm{NO}_{3}\right)_{2} .3 \mathrm{H}_{2} \mathrm{O}$, Abultion indicum leaf have high purity and enlarged 250,000 times calculated based on the literature from [29].

3. The formation of $\mathrm{CuO}$ is assumed to be a complete reaction.

4. Stirring temperature for leaf extraction is $90^{\circ} \mathrm{C}-95^{\circ} \mathrm{C}$ for 3 hours.

5. The time to dry and concentrate the substance in the evaporator is 1 hour. 
6. The stirring speed in the process of homogenizing the leaf extract and $\mathrm{Cu}\left(\mathrm{NO}_{3}\right)_{2} \cdot 3 \mathrm{H}_{2} \mathrm{O}$ in a magnetic stirrer is $2000 \mathrm{rpm}$ in 2-5 minutes.

7. The furnace temperature used to burn the sample is $400^{\circ} \mathrm{C}$ for $2-3$ minutes.

8. Furnace temperature used for calcination is $400^{\circ} \mathrm{C}$ in 2 hours tinggal residence time.

9. Assuming $5 \%$ loss in any mechanical process.

\section{Economic Evaluation}

In this economic evaluation, the price data in the analysis were obtained from several online shops named www.tokopedia.com, www.alibaba.com, and www.sigmaaldrich.com. The data processing in this economic evaluation analysis is processed mathematically using the Microsoft Excel application. The process of economic evaluation in a factory is carried out based on the following parameters:

1. Gross Profit Margin (GPM)

Gross Profit Margin (GPM) is a type of profit which is calculated by subtracting income for one period from the cost of goods sold. The calculation of gross profit margin is the first step to determine the level of profitability of this project [31].

2. Break Even Point (BEP)

Break Even Point (BEP) is the point where income equals invested capital, there is no profit or loss. BEP can be calculated by calculating the value of fixed costs divided by value (total selling price minus total variable price). The calculation of BEP can be in the form of a projection or an estimate of the minimum number of goods that must be sold during a certain period [31].

3. Total Investment Cost (TIC)

Total Investment Cost (TIC) is capitan or initial cost that must be provided at the beginning of production. TIC is usually calculated based on the total cost of the factory (Total Purchasement Cost (TPC)). Simply put, the TIC is the cost to build a factory and initial costs (equipment and service costs realted to equipment for equipment agencies in he factory) [32]. 4. $\quad$ Net Present Value (NPV)

Net Present Value (NPV) is the value obtained from a project which represents expenses and income. The calculation of the NPV must consider the opportunity cost of social capital (as a discount rate). On the other hand, NPV can also be used to estimate expected future financial flows [33].

5. Cumulative Net Present Value (CNPV)

Cumulative Net Present Value (CNPV) is the calculation of the total NPV value from the beginning of factory construction to the end of factory operation. CNPV can be obtained as the amount of cumulative financial flows each year. In addition, CNPV also calculates land and final depreciation, as well as deposit value (final depreciation value) [33]. CNPV is calculated through equation (1) below:

where:

$$
C N P V=\sum N P V=\sum \frac{\left(B_{t}-C_{t}\right)}{(1+i)^{t}}
$$

$\mathrm{B}_{\mathrm{t}}=$ profit

$\mathrm{C}_{\mathrm{t}}=$ cost

$\mathrm{i}=$ one-period social discount rate in period $\mathrm{t}$

$\mathrm{t}=$ time (year)

6. Internal Rate Return (IRR) 


\section{International Journal of Research and Applied Technology}

1(1)(2021) 187-199

Journal homepage: https://ojs.unikom.ac.id/index.php/injuratech

Internal Rate Return (IRR) calculated through equation (2) as follows:

$I R R=\sum_{t-1}^{t} \frac{C_{t}}{(1+r)^{t}}-C_{o}$

where:

$\mathrm{C}_{\mathrm{t}}=$ net cash inflows during period $\mathrm{t}$

$\mathrm{C}_{\mathrm{o}}=$ total investment cost

$\mathrm{r}=$ discount rate

$\mathrm{t}=$ time (year)

7. Profitability Index (PI)

Profitability Index (PI) estimated by dividing the CNPV and the total cost of investment or sales, according to the type of PI profit for each investment or profit for sales [34].

8. Payback Period (PBP)

Payback Period (PBP) is a calculation carried out to predict the length of time it will take for an investment to return the total initial outlay. PBP is calculated when CNPV is at zero for the first time [34].

In determining the economic analysis, there are several assumptions that may occur during the project, including:

1. Calculation of economic evaluation analysis using IDR currency.

2. Calculation of 1 USD is equivalent to $15,0000.00$ IDR.

3. Based on the price sold commercially, the price of Albution indicum leaves is 20,000.00 IDR $/ \mathrm{kg}$ and the price of $\mathrm{Cu}(\mathrm{NO} 3) 2.3 \mathrm{H} 2 \mathrm{O}$ is $60,000.00 \mathrm{IDR} / \mathrm{kg}$. Meanwhile, deionized water is obtained from water treatment which is processed at the factory using a water purifier and it is assumed that the factory is close to a water source.

4. Equipment prices are determined based on commercially available prices with a total equipment purchase cost of 227,475,000.00 IDR.

5. Electricity costs are assumed to be $1.380 .00 \mathrm{IDR} / \mathrm{KWh}$.

6. One cycle of $\mathrm{CuO}$ synthesis process takes 8 hours.

7. Project runs 25 days/month or in one year is 300 days.

8. Total workforce during processing is 50 people with per worker 3,000,000 IDR/month.

9. Income tax $10 \%$.

10. Sales discount rate of $15 \%$.

11. Project duration is 10 years.

\section{Results and Discussion}

\section{Engineering Perspective}

Figure 2 shows the production process of $\mathrm{CuO}$ nanoparticles using the green synthesis method. From an engineering point of view, the total raw material cost per year is $391,500.00$ USD and one year profit is 795,729.49 USD. The selling price in one year is 1,506,250.00 USD. The purchase price of the tools is 15,165.00 USD. This project has been operating for 10 years and PBP has been achieved in the 3rd year because the project has been running well. 


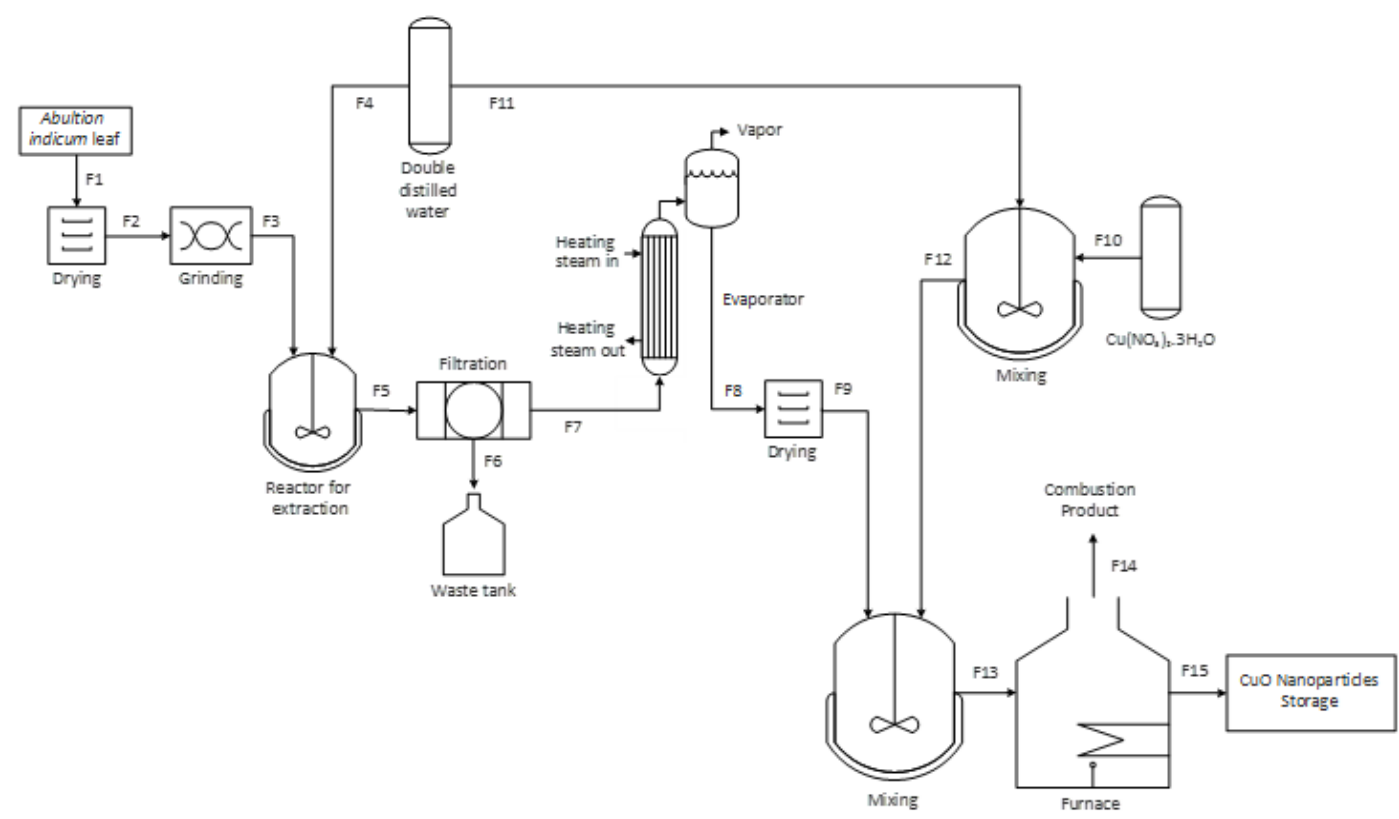

Figure 2. Process flow diagram of $\mathrm{CuO}$ nanoparticles

\section{Ideal Condition}

Figure 3 shows a graph of the relationship between CNPV/TIC and time. The X-axis is year and Y-axis is CPNV/TIC. The graph shows a decrease in income, namely in the 1st to 2nd year, caused by initial capital expenditures for the purchase of equipment needed during the nanoparticle production process as well as for the cost of purchasing land. In that year the factory did not produce nanoparticles. In the 3rd year there is an increase in income, this condition is called Payback Period (PBP) [34]. This increase in revenue because the factory has produced $\mathrm{CuO}$ nanoparticles and sold, it can cover the initial capital used to purchase equipment and land purchase costs. The profit earned continues to increase until the 10 th year. Therefore, the production of nanoparticles is a very profitable project because this project only takes 2 years for initial capital.

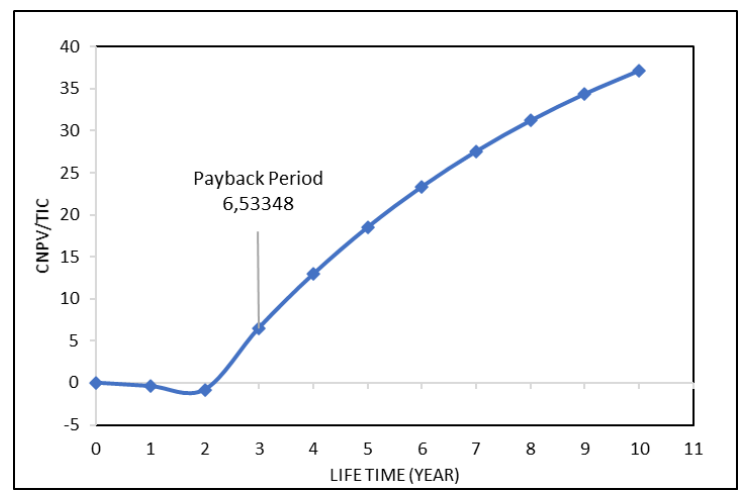

Figure 3. Graph of ten-year CNPV/TIC under ideal conditions

In Table 1, the CNPV/TIC values is negative for the 1st and 2nd years. Then the CNPV/TIC value began to return to positive in the 3rd year with a value of 6.53348 which continued to increase until the 10th year with a value of 37.15863. Therefore, the production of $\mathrm{CuO}$ 
nanoparticles can be considered as a profitable project because the production of $\mathrm{CuO}$ nanoparticles requires a short time to recover the investment costs. This is because the $\mathrm{CNPV} / \mathrm{TIC}$ value fell below 0 in the first 2 years to recover the total initial project expenditure. However, after that there was an increase in the value of CNPV/TIC to a positive value after the second year [35].

Table 1. Annual CNPV/TIC values under ideal conditions

\begin{tabular}{|cc|}
\hline CNPV/TIC & Year \\
\hline 0 & 0 \\
$-0,40986$ & 1 \\
$-0,82759$ & 2 \\
6,53348 & 3 \\
12,93442 & 4 \\
18,50044 & 5 \\
23,34047 & 6 \\
27,54918 & 7 \\
31,20893 & 8 \\
34,39133 & 9 \\
37,15863 & 10 \\
\hline
\end{tabular}

\section{Variation of Sales}

Figure 4 shows a graph of CNPV with various sales variations over 10 years. The analysis was carried out by decreasing and increasing sales by 10 and $20 \%$. Ideal sales are $100 \%$, when sales are decreased by 10 and $20 \%$, the sales are 90 and $80 \%$ respectively. When sales increased by 10 and $20 \%$, the sales are 110 and $120 \%$ respectively. From Figure 4 , sales with various variations have the same value at the beginning of project development (from 1st year to 2nd year). After the project was created (in 3rd year) there was a sales effect on CNPV/TIC. The greater the sales value, the higher the profit from the project being carried out [34]. However, if there are conditions that cause product sales to decline, then the project profits are reduced from the ideal state. Profits continue to increase after reaching the Payback Period point until the 10th year. When sales are reduced by $20 \%$ from ideal conditions, the gap in profits generated each year will be less. Conversely, the gap between the profits generated from each year increases with the increase in sales from ideal conditions. The value of CNPV/TIC in the 10th year for each variation of 80, 90, 100, 110 and 120\% were 23,74224; 30.45043; 37,15863; 43,$86682 ; 50.57501$. From the variety of sales, the project can still run and generate profits.

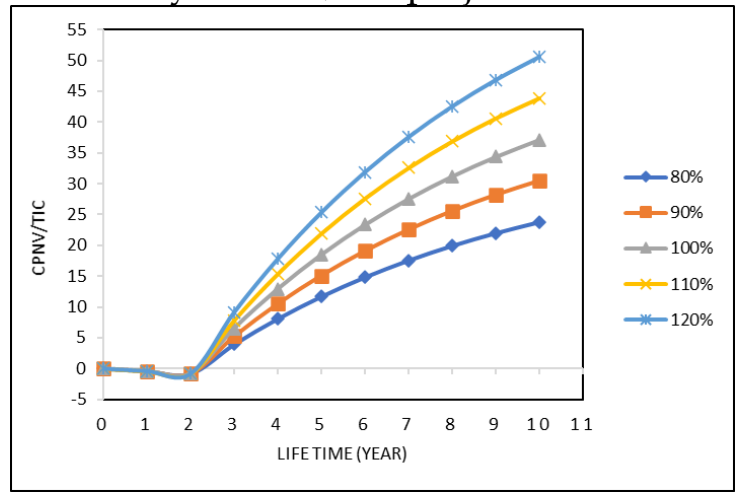

Figure 4. Graph of CPNV/TIC for ten years with sales variations 


\section{Variation of Tax}

Taxes are another levy imposed on projects by the state and is an external factor that can affect the success of a project. Economic evaluation of external factors can actually affect the success of a project. One of the factors is the taxes levied on projects by the state to finance various public expenditures [35].

Figure 5. In the 1st and 2nd year shows the initial conditions of the project. The initial condition of the project on the graph decreased because in the 1st and 2nd year there was no income tax expense and in that year there was a factory construction, so the graph was the same as the ideal graph condition. The variation of taxes in the 3rd to 10th years is increasing, this is very influential on this project. The value of CNPV/TIC obtained in the 10th year with tax variations of $10,25,50,75$, and $100 \%$ were $37.15863 ; 30.85250 ; 20.34230 ; 9.83210 ;-0.67811$. The higher the tax that must be issued, the return on the initial investment will be longer than ideal conditions. The higher the tax issued, the smaller or less profitable the profitability of production [34]. From the CNPV/TIC graph, the higher the tax that must be issued every year, the lower the profitability. Therefore, the maximum tax earned to obtain the BEP or the point at which the project's profit or loss is $75 \%$. If the tax change you get is more than $75 \%$, it can make the project fail.

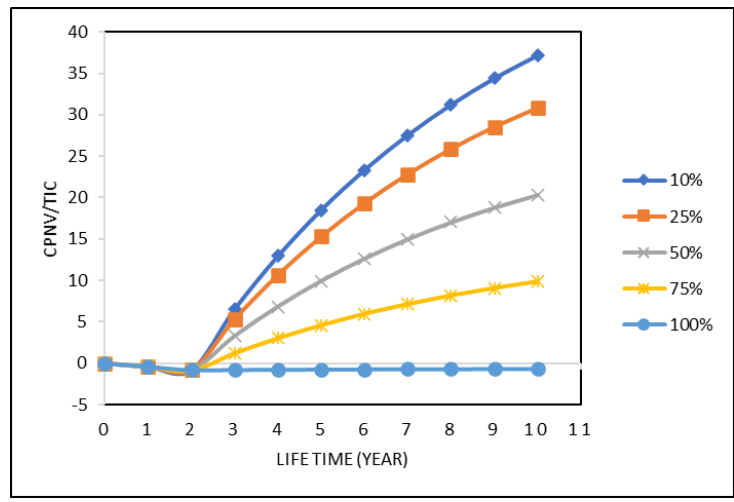

Figure 5. Graph of CPNV/TIC for ten years with tax variations

\section{Variation of Raw Materials}

The success factor of a project can be influenced by the condition of the raw materials. The graph of CNPV against time with variations in raw materials is shown in Figure 6 . The analysis was carried out by decreasing and increasing raw materials under ideal conditions (represented by $100 \%$ ) by 10 and $20 \%$. When the raw material is reduced by 10 and $20 \%$, the raw material becomes 90 and $80 \%$ respectively. When the raw material increases by 10 and $20 \%$ the raw material becomes 100 and $120 \%$ respectively. In the 1 st to 2 nd year show the initial conditions of the project. The initial condition of the project on the CPNV chart under the variation of raw materials has the same CNPV/TIC value and have decreased due to project development. Variations in raw materials will affect the project in the 3rd to 10th year, this is indicated by the CNPV/TIC value which will increase starting in 3rd year for each variation. From Figure 6 it can be concluded that the higher the variation of raw material conditions, the lower the CNPV/TIC value [34]. In the 10th year with variations of $80,90,100,110$, and $120 \%$ the value of CNPV/TIC were 40.90825; 39,03344; 37,15863; 35.28382; 33,40901. From a variety of raw materials, the project can still run and make a profit. Furthermore, the profit will continue to increase after reaching the PBP point until the 10th year. 


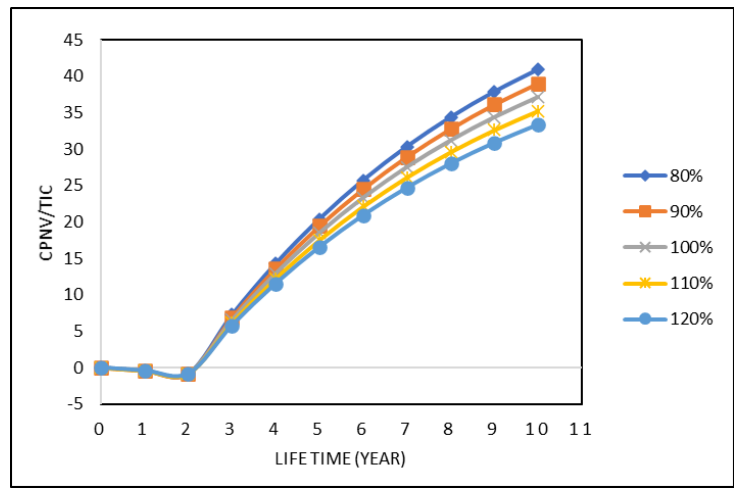

Figure 6. Graph of CPNV/TIC for ten years with raw materials variations

\section{Variation of Labor Wages}

The labor wages factor can also effect the success of a project. The graph of CNPV against time with labor variation is shown in Figure 7. The analysis was carried out by reducing and increasing the salary of labor wages in ideal conditions (represented by $100 \%$ ) by 10 and $20 \%$. When the salary is reduced by 10 and $20 \%$, it will be 90 and $80 \%$ respectively. When the salary is increased by 10 and $20 \%$, it becomes 110 and $120 \%$ respectively. In the 1 st to 2 nd year indicate the initial conditions of the project. The initial project conditions on the CPNV graph under the variation of labor wages have the same CNPV/TIC value and have decreased due to project development. Variations in labor wages will have an effect on the project in the 3rd to 10th year, this is indicated by the CNPV/TIC value which will increase starting in 3rd year for each variation. In the 10 th year with variations of $80,90,100,110$, and $120 \%$ the CNPV/TIC value were $39.07797 ; 38.11830 ; 37,15863 ; 36,19895 ; 35,23928$. The higher the salary of the workers, the lower the profit of the project but the project can go on and make a profit [35]. Furthermore, profits will continue to increase after reaching the PBP point until the 10th year.

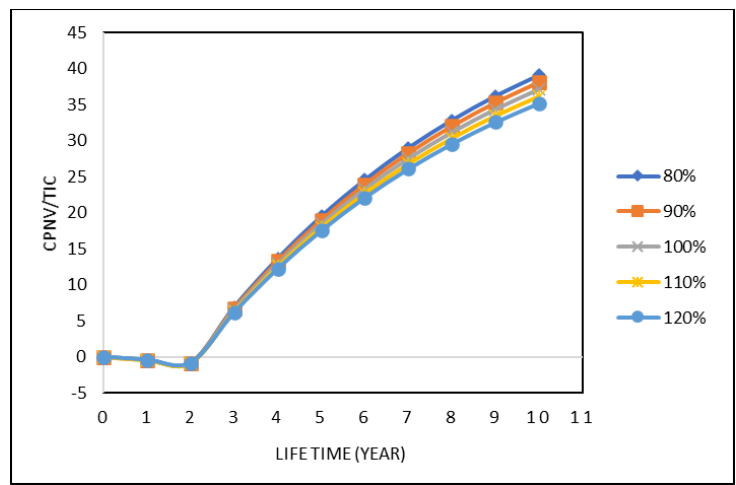

Figure 7. Graph of CPNV/TIC for ten years with labor wages variations

\section{Variation of Utility}

The success of a project can also be affected by the utility. The graph of CNPV against time with utility variations is shown in Figure 8 . The analysis is carried out by decreasing and increasing the utility in an ideal conditions (represented by $100 \%$ ) by 10 and $20 \%$. When the utility is reduced by 10 and $20 \%$, the utility becomes 90 and $80 \%$ respectively. When it is increased by 10 and $20 \%$ the utility becomes 110 and $120 \%$ respectively. In the 1 st to 2 nd year indicate the initial conditions of the project. The initial project condition on the CPNV graph 

development. The utility variation will affect the project in the 3rd to 10th year, this is indicated by the CNPV/TIC value which will increase starting in the third year for each variation. Variations in utility prices have no significant effect on the CPNV/TIC chart [35]. In the 10th year with variations of $80,90,100,110$, and $120 \%$ the CNPV/TIC values were 37.16650 ; 37,$16256 ; 37,15863 ; 37.5469 ; 37.15075$. From the variety of utilities, the project can take place and generate a profit. Furthermore, profits will continue to increase after reaching the Payback Period point until the 10th year.

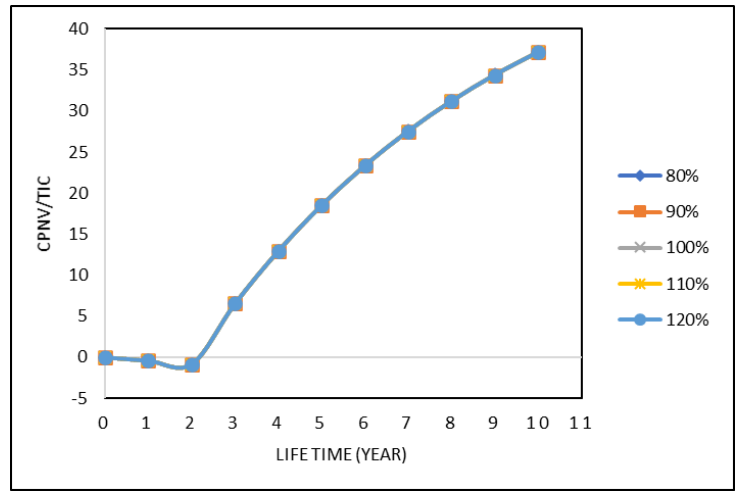

Figure 8. Graph of CPNV/TIC for ten years with utility variations

\section{Conclusion}

Based on the above analysis, the $\mathrm{CuO}$ nanoparticle production project using the green synthesis method is a prospective and economical project because this method is very simple, does not use hazardous materials and is inexpensive. This analysis was obtained from an economic evaluation using several parameters which stated that the $\mathrm{CuO}$ nanoparticle production project was very profitable and had a short payback period of 3 years for the initial investment. This project can compete with PBP capital market standards due to its short return on investment. Analysis of the value of CNPV/TIC and PBP is influenced by several factors such as price variations, sales tax and selling price. The results of our research regarding the economic evaluation of the production of $\mathrm{CuO}$ nanoparticles using the green synthesis method are expected to provide an industrial-scale overview of economic evaluation. From this economic evaluation analysis it can be concluded that this project is feasible to run.

\section{Acknowledgement}

Thank you to the Industrial Chemistry Study Program and the Indonesian Education University for supporting the preparation of this paper. 


\section{International Journal of Research and Applied Technology}

1(1)(2021) 187-199

Journal homepage: https://ojs.unikom.ac.id/index.php/injuratech

\section{References}

[1] Kumar, K.Y., Muralidhara, H.B., Nayaka, Y.A., Hanumanthappa, H., Veena, M.S., \& Kumar, S.K. 2014. Hydrothermal synthesis of hierarchical copper oxide nanoparticles and its potential application as adsorbent for $\mathrm{Pb}$ (II) with high removal capacity. Separation Science and Technology, 49(15), pp. 2389-2399.

[2] Kwak, K.Y., \& Kim, C.Y. 2005. Viscosity and thermal conductivity of copper oxide nanofluid dispersed in ethylene glycol. Korea-Australia Rheology Journal, 17(2), pp.3540.

[3] Iravani, S. 2011. Green synthesis of metal nanoparticles using plants. Green Chemistry, 13(10), pp.2638-2650.

[4] Rahnama, A., \& Gharagozlou, M. 2012. Preparation and properties of semiconductor $\mathrm{CuO}$ nanoparticles via a simple precipitation method at different reaction temperatures. Optical and Quantum Electronics, 44(6), pp.313-322.

[5] Yu, T., Cheong, F.C., \& Sow, C.H. 2004. The manipulation and assembly of CuO nanorods with line optical tweezers. Nanotechnology, 15(12), p.1732.

[6] Safarifard, V., \& Morsali, A. 2012. Sonochemical syntheses of a nano-sized copper (II) supramolecule as a precursor for the synthesis of copper (II) oxide nanoparticles. Ultrasonics sonochemistry, 19(4), pp.823-829.

[7] Nagajyothi, P.C., Muthuraman, P., Sreekanth, T.V.M., Kim, D.H., \& Shim, J. 2017. Green synthesis: In-vitro anticancer activity of copper oxide nanoparticles against human cervical carcinoma cells. Arabian journal of chemistry, 10(2), pp.215-225.

[8] Yang, Q., Wang, Y.E., Yang, Q., Gao, Y., Duan, X., Fu, Q., Chu, C., Pan, X., Cui, X., \& Sun, Y. 2017. Cuprous oxide nanoparticles trigger ER stress-induced apoptosis by regulating copper trafficking and overcoming resistance to sunitinib therapy in renal cancer. Biomaterials, 146, pp.72-85.

[9] Khedekar, V.V., \& Bhanage, B.M. 2016. Simple electrochemical synthesis of cuprous oxide nanoparticles and their application as a non-enzymatic glucose sensor. Journal Of the Electrochemical Society, 163(6), p.B248.

[10] Velusamy, V., Palanisamy, S., Kokulnathan, T., Chen, S.W., Yang, T.C., Banks, C.E., \& Pramanik, S.K. 2018. Novel electrochemical synthesis of copper oxide nanoparticles decorated graphene- $\beta$-cyclodextrin composite for trace-level detection of antibiotic drug metronidazole. Journal of colloid and interface science, 530, pp.37-45.

[11] Mousali, E., \& Zanjanchi, M.A. 2019. Electrochemical synthesis of copper (II) oxide nanorods and their application in photocatalytic reactions. Journal of Solid State Electrochemistry, 23(3), pp.925-935.

[12] Mosleh, S., Rahimi, M.R., Ghaedi, M., Dashtian, K., \& Hajati, S. 2018. Sonochemicalassisted synthesis of $\mathrm{CuO} / \mathrm{Cu} 2 \mathrm{O} / \mathrm{Cu}$ nanoparticles as efficient photocatalyst for simultaneous degradation of pollutant dyes in rotating packed bed reactor: LED illumination and central composite design optimization. Ultrasonics sonochemistry, 40, pp.601-610.

[13] Abbasian, H., Ghanbari, D., \& Nabiyouni, G. 2013. Sonochemical-assisted synthesis of copper oxide nanoparticles and its application as humidity sensor. Journal of NANOSTRUCTURES, 3(4), pp.429-434. 
[14] Zhang, J., Wang, J., Fu, Y., Zhang, B., \& Xie, Z. 2015. Sonochemistry-synthesized CuO nanoparticles as an anode interfacial material for efficient and stable polymer solar cells. Rsc Advances, 5(36), pp.28786-28793.

[15] Arunkumar, B., Jeyakumar, S.J., \& Jothibas, M. 2019. A sol-gel approach to the synthesis of $\mathrm{CuO}$ nanoparticles using Lantana camara leaf extract and their photo catalytic activity. Optik, 183, pp.698-705.

[16] Zayyoun, N., Bahmad, L., Laânab, L., \& Jaber, B. 2016. The effect of pH on the synthesis of stable $\mathrm{Cu} 2 \mathrm{O} / \mathrm{CuO}$ nanoparticles by sol-gel method in a glycolic medium. Applied Physics A, 122(5), p.488.

[17] Siddiqui, H., Parra, M.R., \& Haque, F.Z. 2018. Optimization of process parameters and its effect on structure and morphology of $\mathrm{CuO}$ nanoparticle synthesized via the sol- gel technique. Journal of Sol-Gel Science and Technology, 87(1), pp.125-135.

[18] Ashok, B., Hariram, N., Siengchin, S., \& Rajulu, A.V. 2020. Modification of tamarind fruit shell powder with in situ generated copper nanoparticles by single step hydrothermal method. Journal of Bioresources and Bioproducts, 5(3), pp.180-185.

[19] Bhuvaneshwari, S., \& Gopalakrishnan, N. 2016. Hydrothermally synthesized Copper Oxide $(\mathrm{CuO})$ superstructures for ammonia sensing. Journal of colloid and interface science, 480, pp.76-84.

[20] Araújo, I.M., Silva, R.R., Pacheco, G., Lustri, W.R., Tercjak, A., Gutierrez, J., Júnior, J.R., Azevedo, F.H., Figuêredo, G.S., Vega, M.L., \& Ribeiro, S.J. 2018. Hydrothermal synthesis of bacterial cellulose-copper oxide nanocomposites and evaluation of their antimicrobial activity. Carbohydrate polymers, 179, pp.341-349.

[21] Singh, J., Kumar, V., Kim, K.H., \& Rawat, M. 2019. Biogenic synthesis of copper oxide nanoparticles using plant extract and its prodigious potential for photocatalytic degradation of dyes. Environmental research, 177, p.108569.

[22] Sharmila, G., Pradeep, R.S., Sandiya, K., Santhiya, S., Muthukumaran, C., Jeyanthi, J., Kumar, N.M., \& Thirumarimurugan, M. 2018. Biogenic synthesis of CuO nanoparticles using Bauhinia tomentosa leaves extract: characterization and its antibacterial application. Journal of Molecular Structure, 1165, pp.288-292.

[23] Zaman, M.B., Poolla, R., Singh, P., \& Gudipati, T. 2020. Biogenic synthesis of CuO nanoparticles using Tamarindus indica L. and a study of their photocatalytic and antibacterial activity. Environmental Nanotechnology, Monitoring \& Management, 14, p.100346.

[24] Akintelu, S.A., Folorunso, A.S., Folorunso, F.A., \& Oyebamiji, A.K. 2020. Green synthesis of copper oxide nanoparticles for biomedical application and environmental remediation. Heliyon, 6(7), p.e04508.

[25] Vishveshvar, K., Krishnan, M.A., Haribabu, K., \& Vishnuprasad, S. 2018. Green synthesis of copper oxide nanoparticles using Ixiro coccinea plant leaves and its characterization. BioNanoScience, 8(2), pp.554-558.

[26] Berra, D., Laouini, S.E., Benhaoua, B., Ouahrani, M.R., Berrani, D., \& Rahal, A. 2018. Green synthesis of copper oxide nanoparticles by Pheonix dactylifera L leaves extract. Digest Journal of Nanomaterials and Biostructures, 13(4), pp.1231-1238. 
[27] Makarov, V.V., Love, A.J., Sinitsyna, O.V., Makarova, S.S., Yaminsky, I.V., Taliansky, M.E., \& Kalinina, N.O. 2014. “Green” nanotechnologies: synthesis of metal nanoparticles using plants. Acta Naturae (англоязычная версия), 6(20), pp. 35-44.

[28] Das, S.K., Dickinson, C., Lafir, F., Brougham, D.F., \& Marsili, E. 2012. Synthesis, characterization and catalytic activity of gold nanoparticles biosynthesized with Rhizopus oryzae protein extract. Green Chemistry, 14(5), pp.1322-1334.

[29] Ijaz, F., Shahid, S., Khan, S.A., Ahmad, W., \& Zaman, S. 2017. Green synthesis of copper oxide nanoparticles using Abutilon indicum leaf extract: Antimicrobial, antioxidant and photocatalytic dye degradation activitie. Tropical Journal of Pharmaceutical Research, 16(4), pp.743-753.

[30] Nandatamadini, F., Karina, S., Nandiyanto, A.B.D., \& Ragadhita, R. 2019. Feasibility study based on economic perspective of cobalt nanoparticle synthesis with chemical reduction method. Cakra Kimia (Indonesian E-Journal of Applied Chemistry), 7(1), pp.61-68.

[31] Astuty, A.N., Salsabila, A.R.M., Roslina, D., Aulia, F.N., Shafira, N., Rahayu, N., \& Nandiyanto, A.B.D. 2020. Economic evaluation of carbon nanoparticles production through non-thermal plasma method. Journal Matter Environment Science, 11, pp.19661975.

[32] Frioui, S., \& Oumeddour, R. 2008. Investment and production costs of desalination plants by semi-empirical method. Desalination, 223(1-3), pp.457-463.

[33] Brennan, D.J., \& Golonka, K.A. 2002. New factors for capital cost estimation in evolving process designs. Chemical Engineering Research and Design, 80(6), pp.579-586.

[34] Prabowo, B., Khairunnisa, T., \& Nandiyanto, A.B.D. 2018. Economic Perspective in the Production of Magnetite (Fe3O4) Nanoparticles by Co-precipitation Method. World Chemical Engineering Journal, 2(2), pp.1-4.

[35] Zahra, F., Utami, F.A., Girsang, G.C.S., Mulya, S.Z.M.S., Fentiana, V.D., Putri, Y.K., \& Nandiyanto, A.B.D. 2020. Economic evaluation of zinc oxide nanoparticle production through green synthesis method using Cassia fistula plant extract. International Journal of Energetica, 5(2), pp. 18-24. 